\title{
AL-QURAN DAN DERADIKALISASI PAHAM KEAGAMAAN DI PERGURUAN TINGGI: PENGARUSUTAMAAN ISLAM WASATHIYAH
}

\author{
M. Alifudin Ikhsan \\ Email: um.alifudin93@gmail.com \\ Universitas Negeri Malang
}

\begin{abstract}
Abstrak
Penelitian ini menghadirkan wacana baru dalam kehidupan beragama di perguruan tinggi. Ekstrimisme dan radikalisme menjadi ancaman terbesar dalam iklim akademik. Tulisan ini mencoba memberikan argumen berbeda terhadap pandangan Al-Quran terhadap radikalisme dan upaya yang dapat dilakukan untuk mencegah penyebaran isu radikal di pendidikan tinggi. Metode penelitian yang digunakan adalah deskriptif kualitatif. Hasil dari penelitian ini yakni sebuah formula dan model pengarusutamaan Islam Wasathiyah sebagai upaya untuk deradikalisasi wacana dan aksi keagamaan di kampus.
\end{abstract}

\section{A. Pendahuluan}

Isu radikalisme di lingkungan kampus sudah tidak asing di tengah masyarakat. ${ }^{1}$ Radikalisme seolah menjadi wacana yang selalu disampaikan dalam berbagai seminar atau konferensi ilmiah di kampus. Wacana ini kembali mencuat di permukaan setelah Presiden Joko Widodo menggumpulkan semua Rektor perguruan tinggi se-Indonesia untuk diminta komitmen menangkal radikalisme. ${ }^{2}$ Kampus merupakan lembaga pendidikan tinggi yang mencetak generasi pemimpin masa depan. Pada hakikatnya, ia didirikan sebagai penyedia layanan pendidikan tinggi mulai dari jenjang sarjana hingga doktor. Lembaga pendidikan ini memiliki tingkat kebebasan berpikir dan berpendapat yang dijamin oleh undang-undang. ${ }^{3}$

Ironisnya, kebebasan berpendapat tersebut justru dimanfaatkan oleh kaum ekstrimis radikal dalam menjalin komunikasi dan beraktivitas secara massif. ${ }^{4}$ Kampus berpotensi besar dalam menyebarkan paham radikal dan anti Pancasila. ${ }^{5}$ Kementerian Riset, Teknologi, dan Pendidikan Tinggi, merilis setidaknya terjadi 11

1 Prof. Suko Wiyono dalam penelitiannya menyebutkan bahwa kampus menjadi sarang recruitment kaum radikal untuk kepentingan jihad di Timur Tengah. Penelitian tersebut sekaligus menjadi renungan pemerintah dalam menetapkan dasar filosofis peratuan perundang-undangan yang berlaku.

${ }^{2}$ Menteri Riset Teknologi dan Pendidikan Tinggi mengumpulkan semua Rektor PTN/PTS se Indonesia di Nusa Dua Bali untuk deklarasi anti radikalisme di perguruan tinggi pada 23 September 2017.

3 Undang-undang Nomor 12 tahun 2012 Tentang Pendidikan Tinggi menyebutkan bahwa perguruan tinggi adalah lembaga pendidikan yang independen yang bebas dari praktik politik praktis dan memiliki kebebasan berserikat, berpikir, berkumpul dan berpendapat sesuai dengan Pancasila dan Undang-undang Dasar Negara Republik Indonesia Tahun 1945.

${ }^{4}$ Supriyadi. 2017. Radikalisme di Perguruan Tinggi. Jurnal Merah Putih Jurusan Hukum dan Kewarganegaraan Fakultas Ilmu Sosial Universitas Negeri Malang Volume 1 Tahun 2017 hal. 221

${ }^{5}$ Ibid. hal. 222 
kasus kerusuhan yang terjadi di berbagai kampus sejak tahun 2014 hingga 2017 saat ini. Berbagai kerusuhan di lingkungan kampus tersebut dipengaruhi oleh sentimen antargolongan atau kebijakan pimpinan perguruan tinggi yang memihak golongannya. ${ }^{6}$ Ekstrimisme dan radikalisme menyebabkan masyarakat merasa waswas memasuki dunia kampus. Dari berbagai fenomena radikalisasi di kampus, masjid adalah tempat yang sering dijadikan sebagai pusat kegiatan mereka. ${ }^{7}$

Masjid kampus sebagai tempat peribadatan milik semua warga kampus juga terkadang 'dikuasai' oleh satu golongan yang ekstrim. Kondisi ini mengakibatkan sivitas akademika kampus merasa enggan beraktivitas atau berkegiatan di Masjid. Kehidupan beragama di perguruan tinggi umum (PTU) tentunya berbeda dengan kehidupan beragama di perguruan tinggi keagamaan Islam (PTKI). Menurut Hanifudin, kecenderungan harmonisasi kehidupan beragama di perguruan tinggi umum antar agama dan sesama agama kurang harmonis. ${ }^{8}$ Tidak jarang, kepentingan kampus ditunggangi oleh kepentingan politik golongan tertentu. Namun, dalam kaitannya dengan radikalisasi kehidupan beragama di kampus, kelompok Islam fundamentalis banyak mengambil bagian.

Keberagaman agama dan golongan agama di kampus dipengaruhi oleh beberapa faktor, salah satunya ideologi ${ }^{9}$ golongan yang mereka usung. Jika kita menelaah lebih dalam terkait dengan radikalisme di kampus, hal ini diawali oleh transformasi kebebasan kampus dalam berpendapat tanpa adanya pengawasan yang terstruktur. Sebagian besar kondisi kehidupan beragama di kampus umum memiliki kebebasan lebih dalam bertindak. ${ }^{10}$ Kampus sebagai penyelenggara pendidikan tinggi juga berbicara politik Islam. Padahal, Islam adalah agama yang suci yang tidak boleh dikotori dengan unsur-unsur mementingkan diri sendiri termasuk urusan politik

${ }^{6}$ Kementerian Riset, Teknologi dan Pendidikan Tinggi. 2017. Laporan Triwulan ke-1 Tahun 2017 Kementerian Riset Teknologi dan Pendidikan Tinggi yang diambil dalam Abu Yasid, 2017. Islam Moderat. Jakarta: Penerbit Erlangga hal. 87.

${ }^{7}$ Hartono Ahmad Jaiz. 2008. Aliran dan Paham Sesat di Indonesia. Yogyakarta: Pustaka AlKausar

${ }^{8}$ Moh. Abdur Rouf Hanifudin. 2017. Urgensi Islam Nusantara dalam menangkal radikalisme Islam Anti Pancasila. Prosiding Seminar Nasional Islam Nusantara di Universitas Negeri Malang pada 17 Februari 2017.

9 Ideologi merupakan paham yang diyakini, diimani, dipegang teguh dan dipercaya mampu membawa kepada suatu keadaan yang sesuai dengan tujuan dan visi hidup.

${ }^{10}$ Ahmad Syafii Maarif. 1994. Membumikan Islam. Yogyakarta: Pustaka Pelajar. 
praktis. ${ }^{11}$ Namun ironisnya, justru kampus menjadi tempat kaderisasi untuk memperoleh aktivis Islam yang militan dan kaku. ${ }^{12}$

Banyak kita jumpai berbagai gerakan radikal seperti Hizbut Tahrir Indonesia, Wahabi, ISIS dan berbagai gerakan Islam fundamentalis lainnya di lingkungan pendidikan tinggi. Organisasi-organisasi tersebut membangun kaderisasi melalui pendidikan. ${ }^{13}$ Selain kelompok-kelompok diatas juga terdapat berbagai kelompok Islam lainnya seperti Muhammadiyah, NU, LDII, Persis, dan berbagai sekte aliran lainnya. Berbagai organisasi dan kelompok Islam tersebut menimbulkan kesan "berburu" anggota atau kader baru dengan menghalalkan segala macam cara. Bukan hanya sekedar pamer prestasi, namun juga terkesan menjatuhkan kelompok lainnya. Di Sulawesi Selatan, sepanjang tahun 2015-2017 setidaknya terjadi 6 kasus tawuran antarmahasiswa yang dipicu oleh pemahaman kehidupan beragama di kampus. ${ }^{14}$

Berbagai fenomena tersebut menjadi bagian dari problematika kehidupan beragama yang moderat di perguruan tinggi. Islam sebagai agama, menuntut kita untuk saling bersatu yang terwadahi dalam bingkai ukhuwwah Islamiyah, ukhuwah wathaniyah dan ukhuwah basyariyyah. Saat ini, persatuan dan kesatuan umat Islam terus ingin dicapai. Para ulama' dunia juga membuat poros baru kehidupan beragama dengan istilah Islam Wasathiyah. Gagasan ini mulai digencarkan pada tahun 2015. ${ }^{15}$ Islam Wasathiyah menjadi terobosan baru dalam moderasi Islam di Indonesia. jika hal ini diterjemahkan dalam implementatif kegiatan kampus, maka diharapkan dapat membendung penyebaran paham radikal di lingkungan kampus. Tulisan ini akan membahas berbagai fenomena politik Islam di masjid kampus dengan disertai oleh gagasan aplikatif dan implementasinya dalam kehidupan sehari-hari melalui wacana baru Islam wasathiyah di berbagai bidang kehidupan.

11 Ahmad Syafii Ma'arif. 2017. Islam dan Pancasila sebagai Dasar Negara: Studu tentang Perdebatan dalam Konstituante. Bandung: Mizan. Hal. 16

12 Ibid. hal 8

${ }^{13}$ Ahmad Sahal. 2015. Islam Nusantara. Bandung: Mizan. Hal. 78

${ }^{14}$ Rosidin. 2017. Ideologi Keagamaan yang Moderat dan Toleran dalam Perspektif NormatifHistoris-Yuridis. Prosiding Seminar Nasional Islam Nusantara di Universitas Negeri Malang pada 17 Februari 2017.

${ }^{15}$ Islam wasathiyah menjadi tema konferensi ulama' se-dunia yang diselenggarakan di Mataram Nusa Tenggara Barat saat penyelenggaraan MTQ Nasional ke-26 di NTB setahun setelah konferensi ulama' dunia di Mesir Tahun 2015. 


\section{B. Pembahasan}

\section{Wabah Radikalisasi Agama di Lingkungan Kampus}

Fenomena radikalisasi agama di Indonesia hingga hari ini masih menjadi perbincangan yang menarik dan terus menghangat. Radikalisme masih menjadi masalah serius bagi banyak kalangan termasuk pemerintah. Munculnya isu-isu mengenai radikalisme Islam merupakan tantangan baru yang harus diselesaikan. Isu radikalisme Islam juga mencuat di perbincangan internasional. Radikalisme Islam sebagai fenomena historis-sosiologis merupakan masalah yang banyak dibicarakan dalam wacana politik dan peradaban global akibat kekuatan media dalam menciptakan persepsi masyarakat. Banyak label yang diberikan oleh dunia, khususnya Amerika Serikat untuk menyebut gerakan Islam radikal ini, mulai dari sebutan kelompok garis keras, ekstrimis, militan, Islam kanan, fundamentalis sampai teroris. $^{16}$

Pandangan barat tersebut menjadikan Islam sebagai agama yang eksklusif bagi warga internasional. Dalam perkembangannya, kini umat Islam sering diperlakukan tidak adil di negara-negara dengan mayoritas penduduk non-muslim. Dari sifat eksklusifitas tersebut, muncullah berbagai akar sejarah radikalisme di Indonesia. Pada mulanya, radikalisme dilakukan untuk menentang kolonialisme. Namun dalam perkembangannya, radikalisme yang berkembang di kalangan generasi muda, kini bertujuan untuk menentang negara dan falsafah bangsa. Islam merupakan agama damai yang mengajarkan perdamaian. Sementara yang dimaksud dengan radikalisme adalah gerakan yang berpandangan keras dan kaku dalam menanggapi berbagai problematika kehidupan modern. ${ }^{17}$

Islam tidak pernah membenarkan praktik penggunaan kekerasan dalam menyebarkan agama, paham keagamaan serta paham politik. Tetapi memang tidak bisa dibantah bahwa dalam perjalanan sejarah terdapat kelompok-kelompok Islam yang menggunakan jalan kekerasan untuk mencapai tujuan politik atau mempertahankan paham keagamaannya. Namun, yang harus kita sadari adalah, berbagai penanaman paham radikalisme di lingkungan kampus diawali dari kehidupan beragama. Masjid sebagai tempat untuk beribadah digunakan sebagai

\footnotetext{
${ }^{16}$ Nurcholis Majid. 1995. Pintu-pintu Menuju Tuhan. Jakarta: Paramadina. Hal. 270.

17 Ahmad Syafii Maarif. 2015. Islam dalam Bingkai Keindonesiaan dan Kemanusiaan: Sebuah Refleksi Sejarah. Bandung : Mizan Hal. 117
} 
basis penyebaran paham radikal. ${ }^{18}$ Berbagai aktivitas keagamaan di Masjid rentan dimasuki paham ekstrim dan radikal. Wabah radikalisme agama di kampus disebarkan oleh berbagai organisasi-organisasi Islam di kampus. ${ }^{19}$

Organisasi keislaman kampus yang biasa dikenal dengan istilah Lembaga Dakwah Kampus (LDK) mempunyai peran yang besar dalam menghidupkan suasana keagamaan di lingkungan kampus. Namun, terkadang LDK menjadi basis kajian kaum ekstrimis radikalis dalam membangun jaringan dan kader militan dalam berjihad. Jihad yang mereka artikan sebagai bagian dari membela agama Islam yakni berupaya untuk menegakkan syariat Islam di Indonesia. Istilah radikalisme untuk menyebut kelompok garis keras dipandang lebih tepat ketimbang fundamentalisme, karena fundamentalisme memiliki makna yang interpretable. ${ }^{20}$

Dalam perspektif Barat, fundamentalisme berarti paham orang-orang kaku ekstrim yang tidak segan-segan berperilaku keras dalam mempertahankan ideologinya. Sementara dalam perpektif Islam, fundamentalisme berarti pembaruan yang didasarkan pada al-Quran dan Sunnah. Dalam kaitannya dengan gerakan radikal yang berarti kekerasan, tentu hal ini dilarang oleh agama. Islam mengajarkan kepada manusia untuk tidak berperilaku keras terhadap sesama manusia. Sebagaimana firman Allah SWT dalam surat Asy-Syura ayat 40 yang berbunyi:

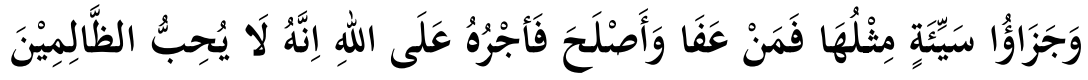

\section{Artinya:}

Dan balasan suatu kejahatan adalah kejahatan yang serupa, maka barangsiapa memaafkan dan berbuat bai, maka pahalanya atas tanggungan Allah. Sesungguhnya Dia tidak menyukai orang-orang yang berbuat dzalim.

Tafsir Al-Misbah menegaskan bahwa ayat di atas mengandung larangan berperilaku keras dalam beraktivitas, termasuk radikal dalam kehidupan beragama. ${ }^{21}$ Ayat tersebut menegaskan kepada kita agar saling menghargai dan menghormati

18 Azumardi Azra. 2015. Fikih Kebhinnekaan: Pandangan Islam Indonesia tentang Umat, Kewarganaan dan kepemimpinan Non-Muslim. Bandung: Mizan.

${ }^{19}$ M. Alifudin Ikhsan. 2015. Divine Solutions from the Quran: Dialektika Langit dan Bumi. Malang: Dream Lintera.

20 Ahmad Nur Fuad. 2015. Dari Reformis hingga Transformatif: Dialektika Keagamaan Muhammadiyah. Malang: Satara Press. Hal. 79

${ }^{21}$ Quraish Shihab. 2002. Tafsir Al Misbah, Pesan, kesan dan keserasian Al-Quran. Jakarta: Lentera Hati. Hal. 386 
kehidupan sesama muslim. Radikalisme agama di kampus menjadi hal yang ironi. Sebagai tempat mencetak kader bangsa, justru disusupi dengan gerakan radikalisme dan intoleransi. Perguruan tinggi umum (PTU) sangat rentang terjangkit virus radikalisme dan ekstrimisme agama. Mengapa demikian? kehidupan akademik di perguruan tinggi umum bersifat heterogen. ${ }^{22}$ Artinya, siapapun dengan bebas dapat masuk ke dalamnya. Kebebasan berpendapat seperti tidak ada batasan yang jelas antara kepentingan kelompok maupun kepentingan akademik kampus.

Sebagai contoh, ekstrimisme kehidupan beragama di kampus tercermin dari banyaknya paham ekstrim yang ingin mengubah dasar negara Pancasila dengan ideologi Islam yang diusung oleh HTI (Hisbut Tahrir Indonesia). Organisasi ini menanamkan pemikiran-pemikiran yang kritis terhadap negara dengan tujuan untuk mengganti falsafah negara. Beberapa kampus juga diketahui menjadi tempat kaderisasi militan yang berangkat ke Timur Tengah untuk berrjuang bersama Islamic State of Irak and Suriah (ISIS). ${ }^{23}$ Mahasiswa menjadi target sasaran gerakan ini karena ia memiliki emosi dan pengetahuan keagamaan yang relatif dangkal. Berbagai kasus pencucuian otak mahasiswa oleh kaum radikalis sering terjadi di berbagai perguruan tinggi. Menteri Riset, Teknologi dan Pendidikan Tinggi mengungkapkan bahwa para teroris dan kaum ekstrimis banyak tumbuh dan berkembang di kalangan akademisi pendidikan tinggi. ${ }^{24}$

Pemahaman mahasiswa terhadap moderasi Islam perlu untuk ditingkatkan kembali. Moderasi yang berarti pandangan jalan tengah yang mengungkapkan sifat Islam rahmatan lil 'alamin harus diimplementasikan dalam kehidupan beragama di lingkungan kampus. Stempel perguruan tinggi umum yang terkadang disebut sebagai perguruan tinggi sekuler juga mempengaruhi stigma masyarakat. ${ }^{25}$ Wabah radikalisasi agama di kampus disebarkan melalui kegiatan-kegiatan kajian keagamaan yang disampaikan oleh lembaga-lembaga dakwah kampus yang intoleran. Stigma sekulerisme pendidikan tinggi di kampus PTU menjadikan para

${ }^{22}$ Heterogen berarti memiliki berbagai kemajemukan dalam segala aspek

23 Dalam pidato Menteri Risetekdikti pada sarasehan nasional ideologi Pancasila sebagai ideologi PT di istana Bogor disampaikan bahwa terdapat 3 mahasiswa perguruan tinggi negeri yang berangkat ke Suriah untuk berjihad bersama ISIS dan sampai saat ini belum diketahui kabarnya.

${ }^{24}$ Pidato Menteri Ristek dan Dikti dalam acara Sarasehan Nasional Ideologi Pancasila sebagai Ideologi Perguruan Tinggi pada 12 September 2017 di Istana Bogor

${ }^{25}$ Hartono Ahmad Jaiz. 2008. Aliran dan Paham Sesat di Indonesia. Yogyakarta: Pustaka AlKausar 
aktivis gerakan radikal masuk mengisi kegiatan-kegiatan keagamaan dengan mengubah mindsed atau pola piker mahasiswa. ${ }^{26}$

\section{Kampus: Sasaran atau Potensi Deradikalisasi}

Sebagai agama samawi $^{27}$ terakhir yang diturunkan Allah melalui Nabi Muhammad SAW, Islam dipersepsikan mengandung ajaran-ajaran moderat di dalamnya. Istilah moderat merupakan bagian dari pemaknaan Islam yang dianggap sebenarnya, walaupun banyak diantara kita yang belum mengerti makna moderat itu sendiri. Berdasarkan penelusuran penulis dari berbagai referensi dan rujukan ${ }^{28}$, istilah moderat sebenarnya terbawa oleh konstalasi sosial politik. Dengan demikian, pembagian Islam menjadi moderat, fundamentalis, liberal, dan ekstrim itu juga tidak lepas dari subjektifitas manusia yang berpendapat. Dalam Islam hanya ada istilah Islam Rahmatan lil 'Alamin. Dari hal ini dapat kita maknai bahwa moderat berarti keseimbangan antara keyakinan dan toleransi. Seperti sebagaimana kita memiliki keyakinan tertentu tetapi mempunyai toleransi yang seimbang terhadap keyakinan yang lain.

Islam yang moderat adalah Islam yang natural, alamiah dan siap untuk diaplikasikan dalam pergulatan hidup dan tentunya belum dimasuki tekanan nonagama. jika sudah dimasuki kepentingan-kepentingan non agama, maka moderat tersebut akan menjadi bias di kalangan masyarakat. Selain moderat kita juga mengenal istilah Islam Wasathiyah. Islam Wasathiyah menjadi genre baru dalam keilmuan Islam yang dapat diterima di dunia internasional. Kata Wasathiyah berasal dari kata wasata yang berarti tengah. Al-Quran juga menyebut secara tegas istilah Wasathiyah dalam surat Al-Baqarah ayat 143 yang berbunyi:

${ }^{26}$ Hilman Latief dan Zezen Zainal Muttaqien. 2015. Islam dan Urusan Kemanusiaan: Konflik, Perdamaian dan Filantropi. Jakarta: Serambi Ilmu Semeste. Hal. 81

${ }^{27}$ Yaitu agama yang diturunkan oleh Allah kepada para rasul urusannya.

${ }^{28}$ Kholes Aboul el-Fadl. 2006. Selamatkan islam dari Muslim Puritan. Jakarta: Serambi Ilmu Semesta; Staphen Sulaiman Schward. 2007. Dua Wajah Islam; Moderatisme vs Fundamentalisme dalam Wawasan Global. Jakarta: Wahid Institute; Ahmad Nur Fuad. 2015. Dari Reformis hingga Transformis: Dialektika Intelektual Keagamaan Muhammadiyah. Malang: Setara Press. 


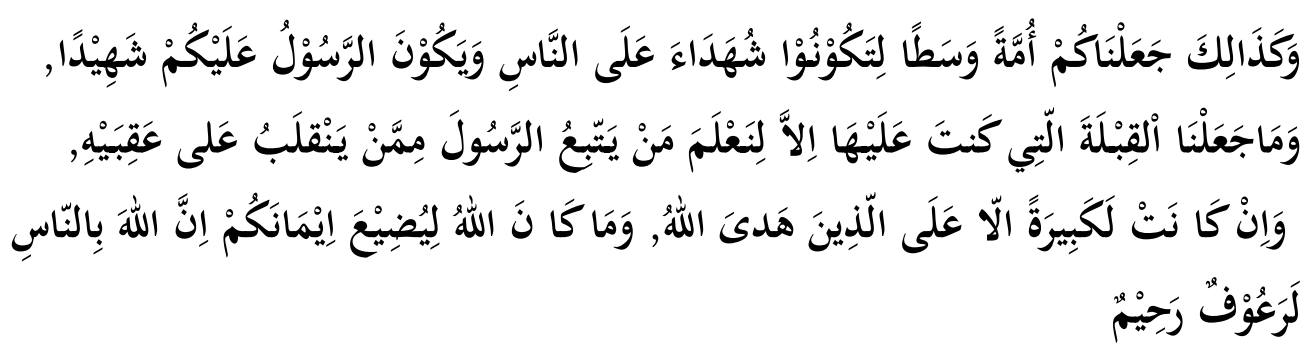

Artinya:

Dan demikian pula kami jadikan kamu (umat Islam) umat yang adil dan pilihan agar kamu menjadi saksi atas perbuatan manusia dan agar rasul Muhammad menjadi saksi atas perbuatanmu. Kami tidak menetapkan kiblat yang menjadi kiblatmu sekarang melainkan agar kami mengetahui siapa saja yang mengikuti Rasul dan siapa saja yang membelot. Dan sungguh pemindahan kiblat tersebut terasa sangat berat kecuali bagi orang yang telah diberi petunjuk oleh Allah. Dan Allah tidak akan mensia-siakan imanmu. Sesungguhnya Allah Maha Pengasih lagi Maha Penyayang kepada manusia.

Dalam Tafsir al-Misbah, Quraish Shihab mengatakan bahwa kata wasata dalam ayat di atas menunjukkan bahwa umat Islam dijadikan sebagai umat pertengahan, yakni umat yang adil dan menjadi pilihan. Mereka akan menjadi saksi atas perbuatan orang yang menyimpang dari kebenaran di dunia maupun di akhirat, serta akan menjadi saksi bahwa para rasul telah menyampaikan risalah kepada kaumnya. ${ }^{29}$ Dalam tafsir Ibnu Katsir dijelaskan bahwa umat Islam adalah umat pertengahan yakni umat yang berada diantara orang-orang yang berlebihan dan orang-orang yang meremehkan. ${ }^{30}$

Dalam struktur ajarannya, Islam Wasathiyah selalu memadukan dua titik ekstremitas yang berbeda dan saling berlawanan. Sebagai contoh, ajaran Islam tidak semata memuat persoalan ketuhanan saja melainkan hal-hal yang menyangkut kemanusiaan dengan beragam implikasinya dalam kehidupan sehari-hari. Lebih detainya, menurut Abu Yasid, komponen Islam mengandung tiga unsur penting yaitu al-Ahkam al-I'tiqodiyah (ajaran tauhis), al-Ahkam al Khuluqiyyah (ajaran etika dan moralitas) dan al-Ahkam al-A'maliyyah (peran aktualisasi Islam dalam keseharian). Hal inilah yang dipegang di beberapa kampus keagamaan Islam di Indonesia. ${ }^{31}$

\footnotetext{
${ }^{29}$ Quraish Shihab. 2002. Tafsir Al Misbah, Pesan, kesan dan keserasian Al-Quran. Jakarta: Lentera Hati. Hal. 106

${ }^{30}$ Ibnu Katsir. 1982. Tafsir Ibnu Katsir Terjemahan Bahasa Indonesia. Bandung: Penerbit Mutiara. Hal. 114

${ }^{31}$ Abu Yasid. 2014. Islam Moderat. Jakarta: Penerbit Erlangga. Hal 8
} 
Pengarusutamaan Islam Wasathiyah di kalangan akademisi tentunya akan berbeda dengan golongan lainnya. Kaum akademisi memiliki pemikiran dan jaringan komunikasi yang luar dan global. Keluasan pemikiran kaum akademik dapat menjadikan Islam sebagai agama yang santun dan tidak radikal. Kaum akademisi memberikan contoh kehidupan sosial yang sejuk dengan nilai-nilai Islam. Sebagaimana telah penulis sampaikan dalam pendahuluan, kecenderungan radikalisme di kampus dipicu oleh jalan pintas pemikiran kalangan akademisi dalam mengatasi problematika kehidupan. Dalam upaya mengarusutamakan Islam menuju Islam wasthiyah ini diperlukan adanya tekad dan komitmen untuk menjalin ukhuwwah Islamiyah dengan bersikap toleransi sesame umat beragama namun berbeda madzhab dan golongan.

Menurut Muhammad Ali, toleransi sebaiknya dilakukan bukan hanya untuk antarumat beragama, namun juga sesame umat beragama. ${ }^{32}$ Toleransi adalah sikap memperbolehkan atau membiarkan ketidaksepakatan atas sikap dan gaya hidup orang lain. Hal ini dipertegas dengan pendapat Scanlon yang mengatakan bahwa toleransi menuntuk manusia untuk menghargai dan menghormati orang lain serta mempersilahkan perbuatan mereka dilakukan meskipun kita tidak sepakat dengan kegiatan itu. ${ }^{33}$ Toleransi sesama umat beragama di kampus seharusnya menjadi bagian dari penanaman nilai-nilai Islam. Namun, egoisme golongan yang merasa 'besar' atau sedang berkuasa atas kampus tersebut, cenderung mengeluarkan kebijakan yang menguntungkan kelompok atau golongannya sendiri.

Kebersamaan dan saling menghargai antar sesama umat beragama akan membangun sebuah kekuatan besar dalam kampus. Toleransi dan saling menghargai antar kelompok merupakan perintah Al-Quran yang telah mengajarkan humanism dalam beragama. Hal ini dapat ditinjau dari Al-Quran surat al-Mumtahanah ayat 8 berikut:

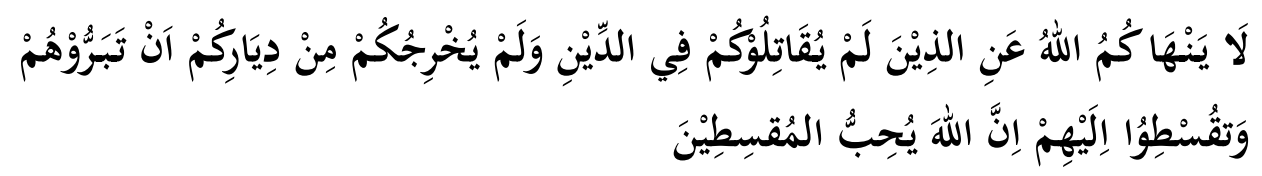

\footnotetext{
${ }^{32}$ Muhammad Ali. 2003. Teologi Pluralis Multikultural. Jakarta: Kompas Media.

${ }^{33}$ Ibid. Hal 17
} 


\section{Artinya:}

Allah tidak melarang kamu untuk berbuat baik dan berlaku adil terhadap orang-orang yang tiada memerangimu karena agama dan tidak pula mengusir kamu dari negerimu. Sesungguhnya Allah menyukai orang-orang yang berlaku adil.

Dalam tafsir al-Azhar disebutkan bahwa Islam sangat menghormati pendapat dan tradisi serta kebiasaan orang-orang yang tidak sealiran dengan kita, dengan syarat mereka tidak memusuhi dan memerangi umat Islam. ${ }^{34}$ Ayat ini berkaitan dengan asbab al-nuzul nya yang dijelaskan oleh Quraish Shihab sebagai berikut:

Asma' binti Abu Bakar menceritakan bahwa ibunya yang ketika itu masih dalam keadaan musyrikah berkunjung kepadanya, kemudian ia pergi menghadap Rasulullah SAW dan bertanya "Bolehkah saya menjalin hubungan baik dengan ibu saya?" kemudian Rasulullah menjawab, "iya, jalinlah hubungan baik dengannya" (HR. Bukhari Muslim) ${ }^{35}$

Oleh karena itu, kalangan akademisi sejatinya memberikan wawasan dan teladan dalam menghargai dan mempelopori wacana Islam Wasathiyah. Berpikir rasional dan berkemajuan secara faktual dan ilmiah untuk memajukan dunia pendidikan tinggi bukan menjadikan kampus sebagai basis gerakan dan penyebaran isu radikal dalam beragama. Radikalisme agama di kampus dapat menjadi catatan pendidikan dan penciptaan suasana keagamaan yang inklusif serta moderat. Kampus dapat menjadi sasaran dan potensi deradikalisasi agama. Potensi yang dimiliki oleh kampus sebagai wadah pengarusutamaan Islam wasathiyah dapat memotong kanal atau jalur penyebaran paham radikal di Indonesia. itulah mengapa, penulis memilih kampus sebagai objek penelitian dalam tulisan ini.

\section{Wacana Baru Islam Wasathiyah di Kalangan Akademisi}

Perguruan tinggi merupakan wadah atau tempat bagi mahasiswa. kampus memiliki banyak keanekaragaman potensi yang dimiliki oleh setiap individu di dalamnya. Baik itu bakat, keahlian, pengetahuan, kepemimpinan, dan intelektual. Berbagai fenomena sosial juga sering mewarnai kehidupan kampus. Di samping itu, mahasiswa masih berusaha mencari jati diri dan pengalaman hidupnya. Ia mencoba untuk memahami langkah dan tujuan kehidupannya mendatang yang masih

${ }^{34}$ Hamka. 2016. Tafsir Al Azhar. Jakarta: Gema Insani

${ }^{35}$ Quraish Shihab. 2002. Tafsir Al Misbah, Pesan, kesan dan keserasian Al-Quran. Jakarta: Lentera Hati. 
dipengaruhi oleh suasana dan faktor lingkungan sosial yang ada di sekitarnya. Karena hal inilah, mahasiswa menjadi sasaran dakwah kaum radikal, yang memanfaatkan kondisi mahasiswa yang masih labil untuk dipengaruhi dengan konsep atau paham radikal yang mereka bawa dengan cara yang halus.

Secara garis besar, gerakan Islam radikal disebabakan oleh faktor ideologi dan non ideologi. Faktor ideologi berkaitan dengan paham Islam yang menjadi dasar kehidupan harusnya diterapkan dalam semua aspek kehidupan termasuk ideologi negara. Faktor non ideologi dapat berupa ekonomi, dendam, sakit hati, ketidakpercayaan dan lain sebagainya. Jika radikalisme berasal dari faktor ideologi, maka hal ini sangat sulit untuk diberantas, karena berkaitan dengan keyakinan seseorang terhadap sesuatu yang benar dalam dirinya. Namun, untuk menetralkan kembali pemikiran yang sudah keras tersebut dibutuhkan waktu yang relatif lama. Faktor ideologi ini hanya dapat diberantas dengan melakukan pendekatan deradikalisasi secara lebih teratur dan tersistem. Sementara faktor kedua (non ideologi) dapat diselesaikan dengan cara memenuhi kebutuhan yang diinginkannya.

Kampus sebagai corong deradikalisasi agama membentuk paham positif dan toleran dalam berbagai aktivitas akademiknya. Sebagai corong wacana Islam Wasathiyah, kampus memiliki jaringan komunikasi yang sangat besar. Sebagai tempat kajian ilmu pengetahuan, kampus juga dapat menyebarkan paham Wasathiyah dalam kehidupan sehari-hari di lingkungan yang lebih besar untuk kemajuan peradaban Islam. Peran kaum akademisi kaum akademisi ini merupakan bagian dari membangun konsep moderat dalam beragama. Sebagaimana firman Allah dalam surat al-Qashash ayat 77 yang berbunyi,

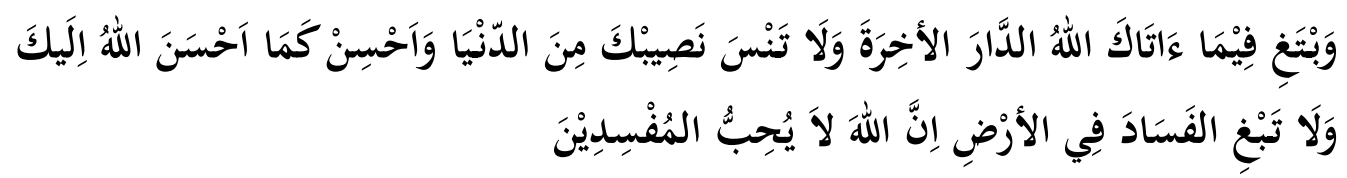

\section{Artinya:}

Dan carilah apa yang telah dianugerahkan kepadaku kebahagiaan negeri akhirat, dan janganlah kau melupakan bagianmu dari kenikmatan dunia dan berbuat baiklah kepada orang lain sebagaimana Allah berbuat baik kepadamu. Dan janganlah kamu membuat kerusakan di muka bumi. Sesungguhnya Allah tidak menyukai orang-orang yang berbuat kerusakan. 
Ayat di atas menurut Quraish Shihab dalam tafsirnya memiliki makna bahwa Islam tidak mengdikotomikan dunia dan akhirat, agama dan politik, politik dan pendidikan dan seterusnya. ${ }^{36}$ Dengan kata lain, kajian agama selalu beriringan dengan kajian-kajian kehidupan lainnya. Begitupula di kampus, sejatinya kampus tidak menjadi bagian dari mesin pencetak generasi radikal, melainkan mencetak generasi moderat dan toleran. Dengan demikian permasalahan radikalisme di kampus dapat diatasi secara perlahan.

Islam Wasathiyah sebagai wacana utama dalam mengatasi deradikalisasi agama di kampus dan menciptakan harmonisasi kehidupan beragama yang moderat, tidak hanya focus dalam menciptakan suasana moderasi melainkan juga mengarusutamakan wacana Islam Wasathiyah ke penjuru dunia. Berikut merupakan beberapa cara implementasi yang dapat dilaksanakan oelh perguruan tinggi sebagai upaya pengarusutamaan Islam Wasathiyah, diantaranya:

1. Membangun kehidupan beragama di kampus yang toleran, inklusif dan moderat melalui penyiapan wadah kemahasiswaan;

2. Mengadakan sosialisasi dan penanaman nilai-nilai moderasi Islam dalam kehidupan kampus melalui berbagai kegiatan di kampus;

3. Membangun komunikasi dan interkoneksi antarperguruan tinggi sebagai mitra kerjasama dalam bidang pengembangan kehidupan beragama di kampus.

Dari berbagai upaya di atas, dapat dijadikan sebagai ikhtiar mengarusutamakan Islam Wasathiyah di perguruan tinggi dalam kehidupan seharihari. Hal ini diharapkan mampu manjaga dan membentengi mahasiswa dari gerakan atau paham radikal yang dibawa oleh kaum radikal di kampus. Dalam mengarusutamakan Islam wasathiyah di kehidupan kampus terdapat beberapa wacana baru dalam mengimplementasikannya. Diantaranya adalah,

1. Islam wasathiyah diterjemahkan dalam bidang ekonomi. Yaitu Lembaga Dakwah Kampus diminta untuk menyediakan layanan entrepreneurship kepada anggotanya. Dengan cara ini radikalisme agama di kampus dapat diatasi dengan pendirian atau penyediaan layanan ekonomi. Ekonomi kemahasiswaan yang

\footnotetext{
${ }^{36}$ Quraish Shihab. 2002. Tafsir Al Misbah, Pesan, kesan dan keserasian Al-Quran. Jakarta:
} Lentera Hati. Hal. 335 
dikelola oleh lembaga dakwah kampus nantinya dapat dijadikan sebagai bagian dari perwujudan islam Wasathiyah di dunia.

2. Islam wasathiyah melalui aktivasi pembelajaran berbasis peer teaching. Kegiatan ini akan membawa dampak positif untuk mengembangkan kepribadian mahasiswa dalam mengajarkan suatu ilmu kepada mahasiswa yang lain tanpa membedakan status sosial dan golongan asalnya.

3. Islam wasathiyah melalui penciptaan wadah atau organisasi kemahasiswaan yang moderat. Organisasi yang moderat ini diciptakan untuk membentuk suatu perkumpulan mahasiswa Islam yang terdiri dari berbagai golongan namun memiliki tujuan yang sama. Organisasi ini dapat berupa organisasi kealquranan misalnya, karena semua organisasi Islam pasti mengimani Alquran. Atau membentuk organisasi kemahasiswaan serupa.

4. Islam wasathiyah dalam politik praktis dapat diimplementasikan dalam menetapkan seorang pemimpin dengan kriteria yang telah ditentukan bersama oleh berbagai organisasi Islam di kampus. Hal ini dapat terwujud jika toleransi dan kebersamaan antargolongan Islam di kampus tersebut terjaga dengan baik.

Dari langkah-langkah di atas dapat dicermati bahwa pelaksanaan program deradikalisasi agama di kampus harus bersifat komprehensif, integral, dan integratif serta berkesinambungan. Hal tersebut dikarenakan radikalisme merupakan paham dan tindakan yang terus menerus aka nada walaupun dengan intensitas yang rendah. Oleh sebab itu, keterlibatan semua pihak sangat dibutuhkan untuk mengawal jalannya deradikalisasi agama di lingkungan kampus. Dalam mencapai sasaran wacana baru Islam wasathiyah di atas dalam proses deradikalisasi kehidupan beragama di kampus, perlu adanya arah kebijakan pimpinan perguruan tinggi dalam menyikapi kondisi ini. Dengan terintegrasinya semua elemen Islam wasathiyah di atas, deradikalisasi agama di kampus akan berjalan dengan lancar.

\section{Penutup}

Islam Wasathiyah merupakan gerakan baru yang muncul di abad ke-21. Gagasan ini muncul sebagai hasil perenungan dan kegelisahan sosial yang terjadi akhir-akhir ini. Radikalisme dan eksklusifisme beragama yang marak terjadi di dunia menjadi latar belakang munculnya gagasan ini. Namun tidak dapat dipungkiri, bahwa 
radikalisme agama juga terjadi di lingkungan pendidikan tinggi. Bahkan kampus sebagai lembaga pencetak generasi muda Indonesia menjadi sasaran dan target radikalisasi agama. Ironisnya, kampus menjadi basis pengkaderan dan penyiapan aktivis gerakan radikal di Indonesia. Islam wasathiyah hadir untuk menjawab problematika kehidupan beragama di kampus melalui pengarusutamaan wacana baru Islam wasathiyah dalam berbagai bidang seperti ekonomi, sosial dan politik.

Moderasi Islam di kampus harus dilakukan untuk mencegah semakin suburnya paham radikalisme beragama di kampus. Kampus menjadi corong pengarusutamaan Islam wasathiyah dengan menjadi pelopor kehidupan yang toleran dan inklusif. Umat Islam sebagai warga agama yang toleran juga memiliki kewajiban untuk mengamalkan nilai-nilai universal (universal values) Al-Quran dalam kehidupan sehari-hari khususnya di lingkungan kampus. Dengan cara inilah, wacana deradikalisasi agama di kampus dapat terwujud.

\section{Daftar Pustaka}

Afadlal. 2005. Islam dan Radikalisme di Indonesia. Jakarta: LIPI Press.

Ali, Muhammad. 2003. Teologi Pluralis Multikultural. Jakarta: Kompas Media.

Arifin, Syamsul. 2003. Islam Indonesia: Sinergi membangun Civil Islam dalam Bingkai Keadaban Demokrasi. Malang: UMM Press.

Azra, Azyumardi. 2015. Fikih Kebhinnekaan: Pandangan Islam Indonesia Tentang Umat, Kewargaan dan Kepemimpinan Non Muslim. Bandung: Mizan.

El-Fadl, Kholes Aboul. 2006. Selamatkan Islam dari Muslim Puritan. Jakarta: Serambi Ilmu Semesta.

Fuad, Ahmad Nur. 2015. Dari Reformis Hingga Transformis: Dialektika Intelektual Keagamaan Muhammadiyah. Malang: Intras Publishing.

Hanafi, Yusuf. 2016. Syariat Islam: Dari Konsepsi Hingga Problematika Legislasi dan Formalisasi. Malang: UM Press

Hanifudin, Muhammad Abdul Rauf. 2017. Urgensi Islam Nusantara dalam Menangkal Radikalisasi Islam dan Gerakan Anti Pancasila. Prosiding Islam Nusantara. Malang: UM Press.

Hikam, Muhammad. 2017. Peran Masyarakat Sipil Indonesia Membendung Radikalisme: Deradikalisasi. Jakarta: Kompas

Huwaidi, Fahmi. 1990. Muwathinun la Dzimmiyun. Kairo: Dar el-Shrouq

Ikhsan, M. Alifudin. 2015. Divine Solutions From The Quran: Dialektika Langit dan Bumi. Malang : Dream Litera.

Ikhsan, M. Alifudin. 2017. "Nilai-nilai Cinta Tanah Air dalam Perspektif Al-Quran". Jurnal Ilmiah Pendidikan Pancasila dan Kewarganegaraan. Vol. 2, no. 2 (Desember 2017). 
Ikhsan, M. Alifudin. 2017. "Fikih HAM dan Kebebasan Beribadah Minoritas Dzimmi”. Jurnal Ilmiah Pendidikan Pancasila dan Kewarganegaraan. Vol. 2, no. 1 (Juli 2017).

Jaiz, Hartono Ahmad. 2008. Aliran dan Paham Sesat di Indonesia. Jakarta: Pustaka AlKausar

Katsir, Ibnu. 1982. Tafsir Ibnu Katsir Terjemahan. Bandung: Penerbit Mutiara.

Latief, Hilman dan Zezen Zainal Mustofa. 2015. Islam dan Urusan Kemanusiaan: Konflik Perdamaian dan Filantropi. Jakarta: Serambi Ilmu Semesta.

Maafif, Ahmad Syafii. 1995. Membumikan Islam. Yogyakarta: Pustaka Pelajar.

----. 2015. Islam dalam Bingkai Keindonesiaan dan Kemanusiaan: Refleksi Sejarah. Bandung: Mizan

-----. 2017. Islam dan Pancasila sebagai Dasar Negara: Studi Tentang Perdebatan Konstituante. Bandung: Mizan.

Majid, Nurcholis. 1995. Pintu-pintu Menuju Tuhan. Jakarta: Paramadina.

Nabhani, Taqiyuddin. 2001. Peraturan Hidup dalam Islam. Jakarta: HTI Press.

Philips, Gerardette. 2016. Melampaui Pluralisme. Malang: Setara Press.

Ragardjo, M. Dawam. 2007. Budaya Damai Komunitas Pesantren. Jakarta: LP3ES.

Rosidin. 2017. Ideologi Keagamaan yang Moderat dan Toleran dalam Perspektif Normatif-Historis-Yuridis. Prosiding Islam Nusantara. Malang: UM Press.

Schwartz, S. Sulaiman. 2007. Dua Wajah Islam: Moderatisme vs Fundamentalisme dalam Wawasan Global. Jakarta: Wahid Institute.

Shihab, Alwi. 1999. Islam Inklusif Menuju Sikap terbuka dalam Beragama. Bandung: Mizan.

Shihab, Quraish. 2012. Membumikan Al-Quran. Bandung: Mizan.

----. 2002. Tafsir Al-Misbah: Pesan, Kesan dan keserasian Al-Quran. Jakarta: Lentera Hati.

Singh, bilveer. 2016. Gerakan Non Mainstream dan Kebangkitan Islam Politik di Indonesia. Yogyakarta: Pustaka Pelajar.

Sutiyono. 2010. Benturan Budaya Islam: Puritan dan Sinkretisme. Jakarta: Kompas.

Thaba, Abdul Aziz. 2000. Islam dan Negara Orge Baru. Jakarta: Gema Insani.

Tim Dosen Pendidikan Agama Islam UM. 2015. Pendidikan Islam Transformatif: Membentuk Pribadi Berkarakter. Malang: Dream Lintera.

Wahid, Abdurrahman. 2015. Islam Nusantara: Dari Ushul Fikih Hingga Paham Kebangsaan. Bandung: Mizan.

-----. 2009. Ilusi Negara Islam. Jakarta: Wahid Institute.

Yasid, Abu. 2014. Islam Moderat. Jakarta: Penerbit Erlangga. 